$$
\begin{gathered}
\text { 레이저광응고술을 시행한 Anterior Zone I 미숙아망막병증에서 } \\
\text { 망막박리의 발생률 및 위험인자 }
\end{gathered}
$$

전남대학교 의과대학 안과학교실, ${ }^{1}$ 조선대학교 의과대학 안과학교실

박상우 · 박정원 · 김대현 $\cdot$ 안재균 · 박영걸 · 허 환*

\title{
Incidence and Risk Factors of Retinal Detachment after Laser Photocoagulation in Anterior Zone I Retinopathy of Prematurity
}

\author{
Sang Woo Park, Jung Won Park, Dae Hyun Kim, Jae Kyoun Ahn, Yeoung Geol Park and Hwan Heo* \\ Department of Ophthalmology, Chonnam National University Medical School and Hospital, \\ ${ }^{1}$ College of Medicine, Chosun University, Gwangiu, Korea
}

\begin{abstract}
The aim of this study was to evaluate the incidence and risk factors of retinal detachment after laser photocoagulation therapy in anterior zone I retinopathy of prematurity (ROP). We performed a retrospective analysis of records of 30 eyes (16 patients) with threshold anterior zone I ROP that were treated with diode laser photocoagulation. We investigated the incidence and time of retinal detachment, birth weight, gestational age, systemic problem, vitreous hemorrhage, the interval between diagnosis of first ROP and threshold ROP, and the number of laser burns. We performed statistical analysis of the risk factors. The total incidence rate of retinal detachment was $43.3 \%$ (13 eyes), and the mean time was $2.85 \pm 2.88$ (range: $1 \sim 12)$ weeks after laser photocoagulation. There were no significant differences in birth weight, gestational age, systemic problem, the interval between diagnosis of first ROP and threshold ROP, or the number of laser burns between the retinal detachment group and no retinal detachment group. The incidences of vitreous hemorrhage in the retinal detachment group and no retinal detachment group were $46.2 \%$ (6 eyes) and $5.9 \%$ ( 1 eye), respectively $(p=0.04)$. The results suggest that vitreous hemorrhage is a risk factor for retinal detachment in threshold anterior zone I ROP after laser photocoagulation therapy. Vitreous hemorrhage should be regarded as a sign of poor prognosis and it is necessary to follow up carefully.
\end{abstract}

Key Words: Retinal detachment; Retinopathy of prematurity; Risk factors

게재결정: 2009년 2월 16일

*교신저자: 허 환, 501-757, 전남대학교 의과대학 안과학교실, Phone: 062-

220-6747, FAX: 062-227-1642, E-mail: opheye@hanmail.net

\section{서 론}

미숙아망막병증은 미숙아에서 망막허혈에 의해 발생되는 혈관신생 증식성망막병증으로 망막박리 등이 발생하여 소아 의 시력장애를 일으킬 수 있는 질환이다. 미숙아 망막병증은 국제분류에 따라 망막의 구역을 zone I, II, III로 구분하고
\end{abstract}


있는데, 그 중 zone I 미숙아망막병증은 치료받은 전체 미숙 아망막병증의 $1 \sim 9 \%$ 를 차지하고 있다. ${ }^{1-3}$ zone II 미숙아망 막병증과 비교하여 zone I 미숙아망막병증은 대부분 360 도 전체에서 발생하고, 편평한 망막 앞 신생혈관을 형성하면서 빠르고 비전형적인 진행을 보여 치료에 잘 반응하지 않는 특징을 갖는다. ${ }^{4,5}$ 이러한 차이는 zone I과 zone II의 혈관형 성 방식의 차이라고 보고된 바 있다. ${ }^{4}$

Zone I 미숙아망막병증에서 치료 후 unfavorable한 결과 를 보이는 경우는 $14.6 \sim 78 \%$ 까지 다양하게 보고되고 있 다. ${ }^{6-8}$ Zone I과 zone II 미숙아망막병증 구분 없이 조사한 보고에 의하면 망막박리를 일으키는 위험인자로 낮은 재태 연령, 문턱단계까지 빠르게 진행하는 경우나 stage 3 의 범위 가 많을 경우, 문턱단계 zone I 미숙아망막병증인 경우, 유 리체출혈이나 기질화가 있는 경우 등으로 알려져 있으나, 레 이저광응고술 후 anterior zone I 미숙아망막병증에서만의 망막박리의 위험인자를 조사한 보고는 없었다. ${ }^{9-11}$ 따라서 저 자들은 zone II와 다른 혈관형성 방식을 보이는 anterior zone I 미숙아망막병증에서 문턱단계에서 레이저광응고술 시 행 후 망막박리의 발생률 및 위험인자를 알아보고자 하였다.

\section{대상 및 방법}

2000년 1월부터 2006년 12월까지 본원 안과에서 anterior zone I 미숙아망막병증으로 진단 받고 광응고술을 시행 받 은 환아 16 명 30 안을 대상으로 의무기록을 후향적으로 조 사하였다. 환아의 재태연령, 출생 시 체중, 패혈증 및 뇌실 내출혈 등 동반된 전신이상 여부, 최초 미숙아망막병증 발견 시기의 연령 및 체중, 최초 미숙아 망막병증의 발견 시기부 터 문턱단계에 이르기까지의 기간, 문턱단계의 미숙아망막 병증 발견시기의 연령 및 체중, 문턱단계 미숙아망막병증의 범위, 레이저광응고술을 시행 받은 시기까지의 기간, 첫 치 료 시 총 레이저 조사 횟수 및 이차 레이저광응고술 여부 등 을 조사하였다. Plus 징후가 있으면서 posterior zone I (시 신경유두에서 황반부까지의 거리를 반지름으로 하는 범위) 에서 발생한 러시형 미숙아망막병증은 예후가 매우 불량하 고 러시형 자체가 망막박리의 위험인자로 알려져 있어 대상 에서 제외하였다. ${ }^{3}$

안저검사는 $2.5 \%$ phenylephrine과 $1 \%$ mydriacyl을 한 방울씩 5 분 간격으로 3 4회 점안하여 산동시키고 $0.5 \%$ proparacaine으로 점안마취 후 도상검안경과 20D 렌즈를
사용하여 시행하였고 주변부 망막의 관찰에는 소아용 공막 압박기를 이용하여 미숙아망막병증의 구역, 단계, plus 징후 유무 및 유리체출혈 등의 안저 변화를 기록하였다.

미숙아 망막병증의 구역과 단계는 미숙아망막병증 분류 위원회의 국제 분류와 Cryo-ROP 연구의 기준에 따라, zone I은 시신경과 황반부 거리의 2 배를 반지름으로 하는 범위로 하였으며, anterior zone I은 zone I에서 posterior zone I을 제외한 망막부위로 하였다. 문턱단계는 plus 징후가 동반되 면서 망막외섬유혈관증식의 범위가 연속적으로 5 시간 이상 이거나 합해서 8시간 이상인 경우로 정의하였다. ${ }^{1,10}$

치료는 anterior zone I 미숙아망막병증이면서 문턱단계에 해당하면 72시간 이내에 도상검안경을 이용한 다이오드 레이 저(Iris Medical Oculight GLx, Iris Medical Instruments, Mountain view, CA, USA) 광응고술을 시행하였다. 시술 은 전신마취 하에 시행하였으며 치료 부위는 융기(ridge)나 망막외섬유혈관증식 부위에서부터 거상연까지의 망막무혈관 부위로 하였고, 응고반은 서로 겹치게 하거나 응고반 사이의 간격을 $1 / 2$ 응고반 직경으로 하여 연속적인 광응고를 시행 하였다. 레이저의 세기는 회백색의 응고반이 생기도록 200 $\sim 450 \mathrm{~mW}$ 로 조정하였고, 조사시간은 $300 \sim 400 \mathrm{msec}$ 로 하였다.

레이저광응고술 후 첫 일주일간은 매일 검사하였고, 그 후 한달 동안에는 환아의 상태에 따라 3 일 또는 일주일 간 격으로 검사하였다. 검사 시마다 plus 징후 진행 및 소실 정 도, 미숙아망막병증의 정도, 유리체출혈 및 망막박리 등의 발생 유무를 기록하였다.

결과에 대한 분석은 SPSS 12.0을 이용하여 Chi-square test, Student T-test 및 univariate와 multivariate logistic regression analysis로 통계 검정하였다.

\section{결 과}

총 16명 30안에서 문턱단계 anterior zone I 미숙아망막 병증으로 진단되어 레이저광응고술을 시행하였다. 16 명 중

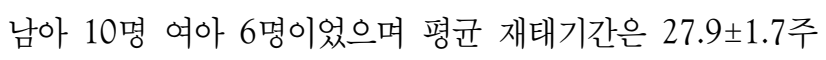
(25 31주), 평균 출생 체중은 $1,016.7 \pm 263.9 \mathrm{gm}$ (640 $1,490 \mathrm{gm})$ 이었다. 뇌실내출혈 및 패혈증이 있었던 환아는 각각 8명(50.0\%)과 3명(18.8\%)이었다. 최초 미숙아망막병 증 발견 시기는 평균 재태연령 $33.9 \pm 1.6$ 주(31 36주), 최 초 미숙아망막병증 발견 시 평균 체중은 $1,409.7 \pm 346.6 \mathrm{gm}$ 
(830 $1,940 \mathrm{gm}$ )이었으며, 문턱단계 미숙아망막병증 진단 시기와 평균 체중은 각각 평균 재태연령 35.3 \pm 1.5 주(33 38 주)와 1,622.6 $4115.4 \mathrm{gm}(990 \sim 2,530 \mathrm{gm})$ 이었고, 망막 외섬유혈관증식의 총 범위는 평균 $7.1 \pm 2.1$ 시간(5 12시간) 이었다. 최초 미숙아망막병증 발견부터 문턱단계까지의 기 간은 평균 $8.6 \pm 5.6$ 일(0 22일), 문턱단계부터 레이저광응 고술까지의 기간은 평균 $17.4 \pm 7.8$ 시간(6 45시간)이었으 며, 1 차 레이저광응고술 시 레이저 총 횟수는 평균 $1,898.1$ \pm 696.0 회(1,120 2,903회) 였다. 2차 레이저광응고술을 시 행한 경우는 10 안(33.3\%)이었고 레이저광응고술 시행 전후 에 유리체출혈이 있었던 경우는 7안(23.3\%)이었다.

총 30 안 중 13 안(43.3\%)에서 레이저광응고술 후 평균

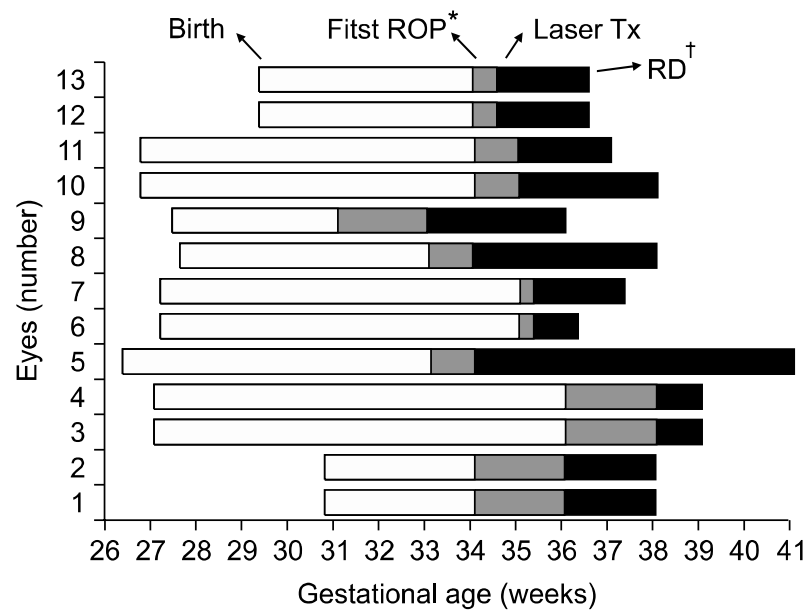

Fig. 1. Time-event diagrams of events occurring after diode laser treatment of threshold anterior zone I retinopathy of prematurity for developing a retinal detachment. *ROP, retinopathy of prematurity; ${ }^{\dagger} \mathrm{RD}$, retinal detachment.
$2.9 \pm 2.9$ 주( 1 12주)에 망막박리가 발생하였다(Fig. 1). 망막 박리가 발생한 군과 발생하지 않은 군간에 재태기간, 출생체 중, 뇌실내출혈 및 패혈증 유무, 최초 미숙아망막병증과 문 턱단계 진단 시기까지의 간격, 망막외섬유혈관증식의 범위, 문턱단계 진단 후 레이저시술까지의 시간, 1 차 레이저광응고 술 시 레이저 총 횟수, 2 차 레이저광응고술의 여부와 유리체 출혈의 빈도를 조사하여 비교하였다(Table 1). 레이저광응고 술을 시행 받은 문턱단계 anterior zone I 미숙아망막병증의 망막박리 위험인자를 알아보기 위하여 univariate와 multivariate logistic regression 분석을 시행하였다(Table 2). 그 결과 유리체출혈이 각각 13 안 중 6 안(46.2\%)과 17 안 중 1 안(5.9\%)으로, univariate와 multivariate 분석에서 모두 유 리체출혈 $(\mathrm{p}=0.025, \mathrm{p}=0.04)$ 이 높은 위험도를 보였다.

\section{고 찰}

본 연구는 문턱단계 anterior zone I 미숙아망막병증을 기준으로 레이저광응고술을 시행하고 발생한 망막박리의 유 병률 및 그 위험인자를 조사하였다. zone I은 시신경유두에 서 황반부까지의 거리를 반지름으로 하는 범위인 posterior zone I과 그 외의 zone I 범위인 anterior zone I으로 세분 할 수 있으며 posterior zone I에서 발생하는 미숙아망막병 증은 러시형으로 조기 치료를 하지 않을 경우 매우 예후가 나쁜 것으로 알려져 있다. ${ }^{3,5,12}$ 본 연구에서는 러시형 미숙아 망막병증 6안은 대상에서 제외되었다.

Zone I 미숙아망막병증은 zone II 미숙아망막병증에 비하 여 드물지만 편평한 망막 앞 신생혈관을 형성하면서 빠르고

Table 1. Comparison of risk factors between retinal detachment group and no retinal detachment group after laser photocoagulation treated for threshold anterior zone I retinopathy of prematurity

\begin{tabular}{|c|c|c|c|}
\hline Risk factor & $\mathrm{RD}^{\dagger}(-)$ group & $\mathrm{RD}^{\dagger}(+)$ group & Total \\
\hline Gestational age at birth (week) & $27.9 \pm 1.8$ & $27.9 \pm 1.5$ & $27.9 \pm 1.7$ \\
\hline Birth weight (gm) & $998.8 \pm 272.4$ & $1,040.0 \pm 261.4$ & $1,016.7 \pm 263.9$ \\
\hline Intraventricular hemorrhage (\%) & 47.1 & 30.8 & 40.0 \\
\hline Sepsis (\%) & 17.6 & 23.1 & 20.0 \\
\hline Age at first diagnosis of ROP* (weeks) & $33.7 \pm 1.8$ & $34.1 \pm 1.3$ & $33.9 \pm 1.6$ \\
\hline Age at first diagnosis of threshold $\mathrm{ROP}^{\star}$ (weeks) & $35.5 \pm 1.5$ & $35.2 \pm 1.5$ & $35.3 \pm 1.5$ \\
\hline Interval between diagnosis of first $\mathrm{ROP}^{*}$ and threshold ROP* (days) & $9.9 \pm 6.3$ & $6.9 \pm 4.2$ & $8.6 \pm 5.6$ \\
\hline Interval between diagnosis of threshold $\mathrm{ROP}^{\star}$ and laser photocoagulation (hours) & $16.3 \pm 8.8$ & $18.9 \pm 6.2$ & $17.4 \pm 7.8$ \\
\hline Total clock hours of stage 3 at threshold ROP* (clock hours) & $6.7 \pm 1.5$ & $7.7 \pm 2.6$ & $7.1 \pm 2.1$ \\
\hline Total number of first laser burn & $2,011.8 \pm 802.9$ & $1,749.38 \pm 518.62$ & $1,798.1 \pm 795.3$ \\
\hline Secondary laser treatment (\%) & 11.8 & 61.5 & 33.3 \\
\hline Vitreous hemorrhage (\%) & 5.9 & 46.2 & 23.3 \\
\hline
\end{tabular}

${ }^{*} \mathrm{ROP}$, retinopathy of prematurity; ${ }^{\dagger} \mathrm{RD}$, retinal detachment. 
Table 2. Univariate and multivariate logistic regression model of risk factors associated with retinal detachment among eyes treated for threshold anterior zone I retinopathy of prematurity

\begin{tabular}{|c|c|c|c|c|}
\hline \multirow{2}{*}{ Risk factor } & \multicolumn{2}{|c|}{ Univariate } & \multicolumn{2}{|c|}{ Multivariate } \\
\hline & $\mathrm{OR}^{*}$ & $p$ value & OR & $p$ value \\
\hline Vitreous hemorrhage & 13.70 & 0.025 & 11.00 & 0.04 \\
\hline Gestational age at birth & 0.99 & 0.987 & - & - \\
\hline Birth weight & 1.00 & 0.667 & - & - \\
\hline Intraventricular hemorrhage & 0.50 & 0.37 & - & - \\
\hline Sepsis & 1.40 & 0.713 & - & - \\
\hline Age at first diagnosis of $\mathrm{ROP}^{+}$ & 1.01 & 0.623 & - & - \\
\hline Age at first diagnosis of threshold $\mathrm{ROP}^{\dagger}$ & 0.91 & 0.712 & - & - \\
\hline Interval between diagnosis of first $\mathrm{ROP}^{\dagger}$ and threshold $\mathrm{ROP}^{\dagger}$ & 0.91 & 0.166 & - & - \\
\hline Interval between diagnosis of threshold $\mathrm{ROP}^{\dagger}$ and laser photocoagulation & 1.05 & 0.368 & - & - \\
\hline Total clock hours of stage 3 at threshold $\mathrm{ROP}^{\dagger}$ & 1.29 & 0.175 & - & - \\
\hline Total number of first laser burn & 0.99 & 0.104 & - & - \\
\hline
\end{tabular}

${ }^{\star} \mathrm{OR}$, Odds ratio; ${ }^{\dagger} \mathrm{ROP}$, Retinopathy of prematurity.

비전형적인 진행을 보이고 레이저광응고술에 잘 반응하지 않는 특징을 갖는다. ${ }^{4.5}$ 이러한 차이는 zone I과 zone II에서 혈관형성의 기전이 달라서 발생한다는 보고가 있는데, zone II에서는 혈관내피세포성장인자(vascular endothelial cell growth factors)의 자극에 의해 기존혈관에서 발아(budding) 를 하는 angiogenesis 형태로 혈관이 생성되지만, zone I에 서는 혈관전구세포(vascular precursor cell)에 의한 vasculogenesis로 혈관생성이 이루어진다고 하였으며, zone I에서 는 혈관내피세포성장인자의 자극보다는 다른 분자적 신호에 의해 혈관생성이 이루어지므로 기존의 혈관내시세포성장인 자의 생성을 감소시키는 레이저 치료에 잘 반응하지 않는다 고 하였다. ${ }^{4}$ Zone I 미숙아망막병증의 치료 결과에 대한 여 러 보고가 있다. 그 중 10 안 이상을 대상으로 한 보고를 살 펴보면 Fleming 등 $^{13}$ 은 zone I 미숙아망막병증 10 안에서 plus 징후가 보이자마자 레이저광응고술을 시행하여 최소 2 년 이상 추적관찰한 동안 unfavorable한 경우는 없었다고 보고하였고, Capone 등 ${ }^{6}$ 은 문턱단계 zone I 미숙아망막병 증 30 안을 레이저 치료하여 평균 31.2 주 추적관찰 기간 동 안 5 안 $(16.7 \%)$ 에서 망막박리가 발생했다고 보고하였다. Vander 등 ${ }^{14}$ 은 36 안의 zone I 미숙아망막병증에서 문턱전 단계에서 치료한 19 안 중 3 안(15.7\%), 문턱단계에서 치료 한 17안 중 3안(17.6\%)에서 unfavorable한 결과를 보고하 였고, Récsán Z 등 ${ }^{15}$ 은 문턱전단계에서 치료한 30 안 중 4 안(13.3\%), 문턱단계에서 치료한 41안 중 8안(19.5\%)에서 unfavorable한 결과를 보였다고 보고하였다. O'Keefe M 등 ${ }^{8}$ 은 24안의 zone I 미숙아망막병증에서 레이저광응고술을 시행한 22안중 16 안(72.7\%)에서 unfavorable한 결과를 보
였으며, 문턱전단계에서 치료한 12 안 중 5 안(41.7\%)에서 favorable한 결과를 보였다고 하였다. 이렇게 zone I 미숙아 망막병증에서 레이저광응고술을 시행한 후 unfavorable한 결과를 보이는 경우가 0 72.7\%까지 다양하게 보고되는 것 은 치료의 시기, 레이저 시술의 숙련도, 추적관찰 기간의 차 이 등에 의한 것으로 생각된다. 본 연구에서는 30 안 중 13 안(43.3\%)에서 망막박리가 발생하였다.

미숙아망막병증에서 망막박리의 위험인자로 낮은 재태연 령, 전신 칸디다혈증과 같은 감염, 문턱단계의 zone I 미숙 아망막병증, 문턱단계로의 빠른 진행, 망막외섬유혈관증식의 범위, 유리체 기질화(vitreous organization) 및 유리체 출혈 (vitreous hemorrhage) 등이 보고 되었다., ${ }^{916-18}$ 본 연구에 서는 망막박리의 위험인자로 환아의 재태연령, 출생 시 체 중, 패혈증 및 뇌실내출혈 등 동반된 전신이상 여부, 최초 미숙아망막병증 발견시기의 연령 및 체중, 최초 미숙아 망막 병증의 발견 시기부터 문턱단계에 이르기까지의 기간, 문턱 단계의 미숙아망막병증 발견시기의 연령 및 체중, 문턱단계 미숙아망막병증의 범위, 레이저광응고술을 시행 받은 시기 까지의 기간, 첫 치료 시 총 레이저 조사 횟수, 이차 레이저 광응고술 여부 및 유리체출혈 여부를 조사하였다. 유리체기 질화 여부는 차트 기록이 불충분하여 조사에 포함하지 않았 다. 통계 분석을 실시한 결과 유리체 출혈이 의미 있는 위험 인자로 나타났다.

유리체출혈이 실험적으로 또는 임상적으로 망막박리를 유 발한다는 기존의 보고들이 있다. ${ }^{6,19-21}$ 토끼에서 안구 손상과 동반되거나 동반되지 않거나 상관 없이 유리체출혈이 유리 체강 내 섬유모세포를 활성화시켜 망막전막, 망막주름 및 망 
막박리 등을 발생시킨다고 보고된 바 있다. ${ }^{20,21}$ Hutcheson 등 $^{22}$ 은 zone I 또는 posterior zone II에서 발생한 문턱단계 미숙아망막병증에서 유리체출혈이 발생한 군과 발생하지 않 는 군간의 비교에서 유리체출혈이 발생하지 않은 군에서는 $91 \%$ 의 favorable한 결과를 보인 반면, 유리체출혈이 발생한 군에서는 $12.5 \%$ 에서만 favorable한 결과를 보였다고 보고 하였다. 또한 유리체출혈 양이 많고 이전에 레이저 치료를 받지 않았거나 무혈관 망막의 범위가 넓을 경우 빠른 유리 체절제술을 고려해야 한다고 하였다. 하지만 신생아에서는 유리체가 망막에 단단하게 붙어 있어 유리체의 완전한 제거 가 어려우며, 진행하고 있는 미숙아망막병증일 경우 수술 중 더 많은 유리체출혈이 발생할 수 있어 오히려 더 심한 unfavorable한 결과를 보일 수 있으므로, plus 징후와 혈관 신생증식 반응이 소실 된 후 수술하는 것이 해부학적인 favorable한 결과를 보일 수 있다고 생각된다.

본 연구는 문턱단계의 zone I 미숙아망막병증에서 망막박 리의 위험인자를 알아보고자 한 것으로, 기존의 zone에 상 관없이 망막박리의 위험인자로 알려진 낮은 재태연령, 문턱 단계로의 빠른 진행, 망막외섬유혈관증식의 범위 등은 zone I 미숙아망막병증에서는 위험인자에 해당되지 않았으며, 유 리체출혈이 유일한 통계적으로 유의한 위험인자였다. 본 연 구에서 망막박리의 발생률은 총 30 안 중 13 안(43.4\%)으로 기존의 보고에 비하여 높게 나타났는데, favorable한 결과에 해당하는 비측 망막박리 및 국소적인 망막박리도 포함되었 으며 문턱단계에서 레이저광응고술을 시행한 것이 원인이라 고 생각된다.

미숙아망막병증에서 문턱전단계에 레이저광응고술을 시행 하여 더 좋은 결과를 보인다는 여러 보고들이 있다. ${ }^{12,14,15,23}$ 현재 본원에서는 문턱단계가 아닌 $\mathrm{ETROP}$ 기준 ${ }^{24}$ 에 따라 zone I 미숙아망막병증의 경우 stage에 상관없이 plus 징후 가 있으면 바로 레이저광응고술을 시행하고 있으며 기존 문 턱단계에서 시행하였을 경우보다 더 좋은 결과를 보이고 있 다. 하지만, 빠른 레이저를 시행하여도 수술 전 후에 유리체 출혈이 있을 경우 좀 더 좋지 않은 예후의 경향을 보인다. 본 연구의 제한점은 레이저시술이 한 명에 의해서 이루어 지지 않았고 유리체출혈의 양이나 시기에 따른 구분이 되어 있지 않은 점, 그리고, 또 다른 위험인자로 가능성 있는 유 리체 기질화에 대한 조사가 되지 않은 점 등이다.

결론적으로 anterior zone I 미숙아망막병증에서 유리체 출혈이 레이저광응고술 후 망막박리의 위험인자라고 생각되 며 유리체출혈이 있을 경우 망막박리의 가능성을 염두에 두
고 좀더 세심한 추적관찰이 필요할 것으로 생각된다.

\section{References}

1. International committee for the classification of retinopathy of prematurity. The international classification of retinopathy of prematurity revisited. Arch Ophthalmol 2005;123:991-9.

2. Cryotherapy for Retinopathy of Prematurity Cooperative Group. Multicenter trial of cryotherapy for retinopathy of prematurity. Three-month outcome. Cryotherapy for Retinopathy of Prematurity Cooperative Group. Arch Ophthalmol 1990;108:195-204.

3. Nissenkorn I, Kremer I, Gilad E, Cohen S, Ben-Sira I. 'Rush' type retinopathy of prematurity: report of three cases. $\mathrm{Br} J$ Ophthalmol 1987;71:559-62.

4. Flynn JT, Chan-Ling T. Retinopathy of prematurity: two distinct mechanisms that underlie zone 1 and zone 2 disease. Am J Ophthalmol 2006;142:46-59.

5. Kychenthal A, Dorta P, Katz X. Zone I retinopathy of prematurity: clinical characteristics and treatment outcomes. Retina 2006;26(Suppl 7):S11-5.

6. Capone A, Diaz-Rohena R, Sternberg P Jr, Mandell B, Lambert HM, Lopez PF. Diode-laser photocoagulation for zone 1 threshold retinopathy of prematurity. Am J Ophthalmol 1993;116:444-50.

7. Axer-Siegel R, Maharshak I, Snir M, Friling R, Ehrlich R, Sherf I, et al. Diode laser treatment of retinopathy of prematurity: anatomical and refractive outcomes. Retina 2008;28:839-46.

8. O'Keefe M, Lanigan B, Long VW. Outcome of zone 1 retinopathy of prematurity. Acta Ophthalmol Scand 2003;81:614-6.

9. Schaffer DB, Palmer EA, Plotsky DF, Metz HS, Flynn JT, Tung B, et al. Prognostic factors in the natural course of retinopathy of prematurity. The Cryotherapy for Retinopathy of Prematurity Cooperative Group. Ophthalmol 1993;100:230-7.

10. Cryotherapy for Retinopathy of Prematurity Cooperative Group. Multicenter trial of cryotherapy for retinopathy of prematurity. One-year outcome-structure and function. Cryotherapy for Retinopathy of Prematurity Cooperative Group. Arch Ophthalmol 1990;108:1408-16.

11. Coats DK. Retinopathy of prematurity: involution, factors predisposing to retinal detachment, and expected utility of preemptive surgical reintervention. Trans Am Ophthalmol Soc 2005;103:281-312.

12. Kim SY, Kim, SJ, Yu, YS. Early ler treatment of rush-type retinopathy of prematurity. J Korean Ophthalmol Soc 2005;46:448-55.

13. Fleming TN, Runge PE, Charles ST. Diode laser photocoagulation for prethreshold, posterior retinopathy of prematurity. Am J Ophthalmol 1992;114:589-92.

14. Vander JF, Handa J, McNamara JA, Trese M, Spencer R, Repka MX, et al. Early treatment of posterior retinopathy of prematurity: a controlled trial. Ophthalmol 1997;104:1731-5.

15. Récsán Z, Vámos R, Salacz G. Laser treatment of zone I prethreshold and stage 3 threshold retinopathy of prematurity. J Pediatr Ophthalmol Strabismus 2003;40:204-7.

16. Gotz-Wieckowska A, Rydlewska-Fojut M, Siennicka A, BurchardtKroll E, Gadzinowski J. The analysis of failure diode laser treatment of active phase of retinopathy of prematurity. Klin Oczna 2006; 
108:39-42.

17. Noyola DE, Bohra L, Paysse EA, Fernandez M, Coats DK. Association of candidemia and retinopathy of prematurity in very low birthweight infants. Ophthalmol 2002;109:80-4.

18. Hartnett ME, McColm JR. Fibrovascular organization in the vitreous following laser for ROP: implications for prognosis. Retina 2006; 26(Suppl 7):S24-31.

19. Ferrone PJ, de Juan E Jr. Vitreous hemorrhage in infants. Arch Ophthalmol 1994;112:1185-9.

20. Cleary PE, Ryan SJ. Histology of wound, vitreous, and retina in experimental posterior penetrating eye injury in the rhesus monkey. $\mathrm{Am}$ J Ophthalmol 1979;88:221-31.
21. Ehrenberg M, Thresher RJ, Machemer R. Vitreous hemorrhage nontoxic to retina as a stimulator of glial and fibrous proliferation. $\mathrm{Am}$ J Ophthalmol 1984;97:611-26.

22. Hutcheson KA, Nguyen ATQ, Preslan MW, Ellish NJ, Steidl SM. Vitreous hemorrhage in patients with high-risk retinopathy of prematurity. Am J Ophthalmol 2003;136:258-63.

23. Kim EH, Lee JE, Choi HY, Oum BS. Outcome of diode laser photocoagulation for threshold and prethreshold retinopathy of prematurity. $J$ Korean Ophthalmol Soc 2007;48:285-90.

24. Hardy RJ, Palmer EA, Dobson V, Summers CG, Phelps DL, Quinn GE. Risk analysis of prethreshold retinopathy of prematurity. Arch Ophthalmol 2003;121:1697-701. 